\title{
Psychological Stress can Trigger Atopic Dermatitis in NC/Nga Mice: An Inhibitory Effect of Corticotropin-Releasing Factor
}

\author{
Hiroo Amano*,', Izumi Negishi', Hiroshi Akiyama ${ }^{2}$ and Osamu Ishikawa' \\ 'Department of Dermatology, Gunma University Graduate School of Medicine, Maebashi, Gunma, Japan; ${ }^{2}$ Division of Foods, National Institute of \\ Health Sciences, Tokyo, Japan
}

\begin{abstract}
Atopic dermatitis (AD) is one of the most common inflammatory diseases of the skin and is usually associated with a family history of atopic diathesis. It has been well established that many environmental or psychological factors aggravate AD. However, it is not clear whether psychological stress by itself can trigger AD. We examined the effect of psychological stress on the onset of AD, using an animal model, the NC/Nga mouse. The animals were exposed to the water avoidance stress (WAS) test to induce psychological stress. Additionally, we examined how corticotropin-releasing factor (CRF) affected the development of AD induced by psychological stress. Under specific pathogen-free (SPF) conditions, NC/Nga mice did not develop AD-like skin lesions. In contrast, NC/Nga mice exposed to psychological stress developed AD-like skin lesions along with elevated levels of serum immunoglobulin E even when kept under SPF conditions. The AD-like skin lesions induced by WAS were completely blocked by pretreating the animals with CRF. Our data indicate that a psychological factor is capable of eliciting AD-like skin lesions in NC/Nga mice. It is possible that the inhibitory effect of CRF may be mediated by the functional modification of various cells that have CRF receptors.

Neuropsychopharmacology (2008) 33, 566-573; doi:I0.1038/sj.npp. I30 I435; published online 25 April 2007
\end{abstract}

Keywords: psychological stress; atopic dermatitis; NC/Nga mice; corticotropin-releasing factor; scratching behavior

\section{INTRODUCTION}

Atopic dermatitis (AD) is a common skin disease characterized by pruritus and eczematous skin lesions in characteristic locations, and by a chronically relapsing course (Hanifin, 1982; Leung and Bieber, 2003). Additionally, AD is usually associated with a family history of atopic diathesis, indicating that $\mathrm{AD}$ is a genetic disorder (Uehara and Kimura, 1993; Kuster et al, 1990). Many patients have elevated serum levels of immunoglobulin E (IgE) against many kinds of allergens, such as mites and dust. It has been well established that such allergens can trigger or exacerbate AD (Rudikoff and Lebwohl, 1998).

The NC/Nga mouse, an inbred strain established by Kondo (Nagoya University, Nagoya, Japan), is an AD animal model and has been extensively studied. NC/Nga mice spontaneously develop AD-like eczematous skin lesions when kept under conventional conditions, but not under specific pathogen-free (SPF) conditions (Matsuda et al, 1997). Under conventional conditions, eczematous skin lesions develop at the age of 8 weeks with maximum activity at around 17 weeks and characterized by edema, hemorrhage, erosion, and dryness. The skin lesions are typically localized to the face, ears, neck, and back (Matsuda

*Correspondence: Dr H Amano, Department of Dermatology, Gunma University Graduate School of Medicine, 3-39-22 Showa-machi, Maebashi, Gunma 37I-85।I, Japan, Tel: +81 27220 8284, Fax: + 8127220 8285, E-mail: hamano@showa.gunma-u.ac.jp

Received 14 September 2006; revised 19 March 2007; accepted 26 March 2007 et al, 1997; Suto et al, 1999; Matsumoto et al, 1999; Yagi et al, 2002). In addition, the elevation of plasma IgE levels correlates with the appearance of the AD-like skin lesions. Histologically, skin lesions show marked hyperkeratosis and some parakeratosis, mononuclear cell infiltration, and degranulation of mast cells and eosinophils in the dermis (Matsuda et al, 1997).

There has been a lot of interest in stress since the groundbreaking work by Selye (1946). A considerable amount of research has focused on the body's general adaptation to acute and chronic stress, especially the effect of stress on the hypothalamic-pituitary-adrenal (HPA) axis, inflammation, and immunity, as well as various psychological and social parameters (Sternberg et al, 1989a, b; van de Langerijt et al, 1994). There have been significant advances on the understanding of intestinal responses to stress (van de Langerijt et al, 1994). For example, psychological stress reactivates inflammatory bowel disease in humans and rats (Million et al, 1999; Levenstein et al, 2000; Bennett et al, 1998). Castagliuolo et al (1996) reported that immobilization stress caused colonic mucin release and mast cell degranulation in rats. These changes were reproduced by corticotropin-releasing factor (CRF), and pretreatment with CRF receptor antagonist inhibited the response to stress. Santos et al (2000) showed that water avoidance stress (WAS) was a good psychological stress model. They demonstrated that WAS caused an epithelial barrier defect and epithelial mitochondrial damage of the colon, in parallel with mucosal mast cell hyperplasia and activation (Santos et al, 2001). 
Patients with $\mathrm{AD}$ often feel frustration when exposed to stressful events, and then experience increased pruritus and scratching (Wamboldt et al, 2003). On clinical observation, psychological problems seem to contribute to 'habitual scratching', which is difficult to manage (Leung and Bieber, 2003). It is possible that $\mathrm{AD}$ patients cannot restrain from scratching to reduce or relieve stress. The aim of our experiment was to investigate whether or not psychological stress by itself can trigger the development of $\mathrm{AD}$ in NC/Nga mice. We chose WAS as a model of psychological stress, expecting similar effects and modes of action as seen in the rat intestinal disease models (Santos et al, 2000; Bonaz and Tache, 1994).

\section{MATERIALS AND METHODS}

\section{Mice}

SPF NC/Nga male mice at the age of 8-10 weeks were purchased from Japan SLC (Shizuoka, Japan) and were kept in an SPF environment. Conventional NC/Nga mice at the age of 8-12 weeks were purchased from Japan SLC separately and remained separate from the SPF mice. Agematched $\mathrm{BALB} / \mathrm{c}$ mice were maintained in the same room with the SPF NC/Nga mice under SPF conditions. All animal experiments were approved by the Animal Care Committee at Gunma University.

\section{The Stress Model (WAS Protocol)}

WAS as reported by Santos et al (2000) was chosen as the model of psychological stress. WAS consisted of placing a mouse for $1 \mathrm{~h}$ on a glass platform (height from floor, $11 \mathrm{~cm}$; diameter, $7 \mathrm{~cm}$ ) located in the middle of a plastic container $(60 \times 58 \mathrm{~cm})$ filled with sterile water up to $1 \mathrm{~cm}$ below the level of the platform (Figure 1). Stress sessions were performed between 1000 and 1300 hours to minimize the effect of the circadian rhythm. SPF NC/Nga mice were divided into two groups. In the control group (SPF control mice), the mice were kept in their cages without handling to avoid sham stress. The SPF control mice were killed without WAS after 4 weeks (at 12-14 weeks of age). The other group (SPF WAS mice) was exposed to the WAS protocol daily for 4 weeks.

\section{Evaluation of Dermatitis}

The clinical severity score for dermatitis was evaluated by the previously described criteria for human AD (Leung et al, 1990) as follows: no symptoms (score 0), light (score 1 ), mild (score 2), and severe (score 3 ). This scoring was assessed for the severity of itch, erythema (hemorrhage), edema, excoriation (erosion), and scaling (dryness). The total score of these four symptoms was computed to determine the score for each mouse (ie minimum 0maximum 15). The clinical severity score was determined by two investigators who were blind to the experiments. Inter-observer error did not vary by more than $3 \%$.

\section{Histochemistry}

After being given WAS for 4 weeks and/or being kept in their cages without WAS for 4 weeks, we performed skin biopsies. Skin biopsy specimens were fixed with $10 \%$ formalin in neutral buffer overnight and embedded in
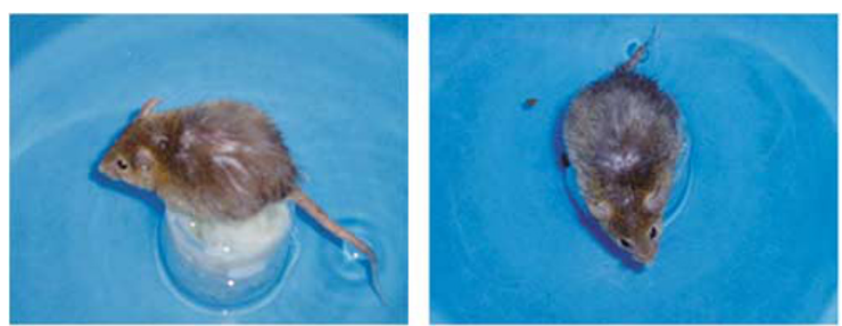

Figure I WAS conditions. A mouse was placed on a glass platform located in the middle of a plastic container filled with water up to $1 \mathrm{~cm}$ below the level of the platform. The mouse on the platform cannot escape even if it jumps.

paraffin. Deparaffinized sections $(3-5 \mu \mathrm{m}$ thick) were stained with hematoxylin and eosin (HE), or $0.05 \%$ toluidine blue $(\mathrm{pH} 7.0)$.

\section{Scratching}

The number of scratching movements was counted for 60 min. We scored scratching behavior using videotape. Scoring of scratching was also performed by two investigators who were blind to the experiments. Inter-observer error did not vary by more than $5 \%$.

\section{Drugs}

CRF (Peptide Institute Inc., Osaka, Japan) was dissolved in phosphate-buffered saline (PBS) according to the manufacturer's instructions, aliquoted and kept frozen at $-70^{\circ} \mathrm{C}$ until use. Immediately before the experiments, CRF was diluted in physiological saline at a concentration of $50 \mu \mathrm{g} / \mathrm{kg}$ for intraperitoneal injection.

\section{CRF Protocol}

A previous report showed that this dose $(50 \mu \mathrm{g} / \mathrm{kg})$ of CRF was enough to elicit the maximal intestinal short-circuit current responses (Santos et al, 1999). The mice were injected intraperitoneally with CRF between 1000 and 1300 hours daily for 4 weeks. In another group, CRF was injected intraperitoneally $30 \mathrm{~min}$ prior to performing the WAS protocol. In the CRF protocol, two groups were injected with saline to be used as controls. In one group, the mice were injected intraperitoneally with saline between 1000 and 1300 hours daily for 4 weeks. In the other group, the mice were injected intraperitoneally with saline $30 \mathrm{~min}$ prior to performing the WAS protocol.

Astressin (Sigma, St Louis, USA) was dissolved in PBS according to the manufacturer's instructions, aliquoted and kept frozen at $-70^{\circ} \mathrm{C}$ until use. Immediately before the experiments, astressin was diluted in physiological saline to a final concentration of $250 \mu \mathrm{g} / \mathrm{kg}$ (Santos et al, 1999) and injected intraperitoneally $30 \mathrm{~min}$ prior to performing the WAS protocol. We chose the doses of astressin based on Santos's report (Santos et al, 2000) and Akiyama's report (Akiyama et al, 2005).

Spantide (Peptide Institute Inc., Osaka, Japan) was dissolved in distilled water according to the manufacturer's instructions, aliquoted and kept frozen at $-20^{\circ} \mathrm{C}$ until use. Immediately before the experiments, spantide was diluted in physiological saline to a final concentration of $50 \mathrm{nM}$ for 
intraperitoneal injection. Spantide was injected intraperitoneally $30 \mathrm{~min}$ prior to performing the WAS protocol.

\section{Measurement of Total IgE}

IgE levels were measured by a sandwich ELISA method according to the manufacturer's instructions (Bethyl Laboratories, Inc.; Montgomery, Texas, USA). Briefly, blood was collected after decapitation, and serum was separated by centrifugation at $500 \mathrm{~g}$ for $30 \mathrm{~min}$. The sera were stored at $-20^{\circ} \mathrm{C}$ until use. Immunoplates were coated with $100 \mu \mathrm{l}$ of goat anti-mouse IgE-affinity-purified antibody and blocked with $0.05 \mathrm{M}$ Tris supplemented with $1 \%$ BSA. Collected samples or standard mouse IgE were added to the wells and incubated for $1 \mathrm{~h}$ at room temperature. After washing with Tris containing $0.05 \mathrm{M}$ Tween 20,100 $\mu$ l of goat anti-mouse IgE-HRP-conjugated antibody were added, and the plates were incubated for $1 \mathrm{~h}$. Then, $100 \mu \mathrm{l} 3,3^{\prime}, 5,5^{\prime}$-tetramethylbenzidine (TMB) (Dako Corporation, Carpinteria, CA, USA) was added. After incubation for $20 \mathrm{~min}$, the reaction was terminated by adding $2 \mathrm{M} \mathrm{H}_{2} \mathrm{SO}_{4}$. Wells were read spectrophotometrically at $450 \mathrm{~nm}$. The sensitivity of this system was $3.9 \mathrm{ng} / \mathrm{ml}$.

\section{Cytokine Assay}

Serum levels of interleukin (IL)-4, IL-5, and interferon (IFN)- $\gamma$ were measured by ELISA development system quantitation kits provided by R\&D Systems, Inc. (Minneapolis, MN, USA) according to the manufacturer's protocol. The sensitivities of these systems for IL-4, IL-5, and IFN- $\gamma$ were $7.8,15.625$, and $15.625 \mathrm{pg} / \mathrm{ml}$, respectively. In addition, the production of IL-4, IL-5, and IFN- $\gamma$ by cultured lymph node (LN) cells from each mouse was measured. In total, $0.5 \times 10^{6}$ cells $/ \mathrm{ml} \mathrm{LN}$ cells were cultured in 96-well roundbottom plates at $37^{\circ} \mathrm{C}$ for $72 \mathrm{~h}$ in complete RPMI 1640 in the absence or in the presence of $5 \mu \mathrm{g} / \mathrm{ml}$ concanavalin A (Con A) (Biogenesis, NH, USA). The culture supernatants were assayed as described above.

\section{Fecal Pellet Output}

The number of fecal pellets expelled by each mouse per hour during WAS or during the same period for the control group while in their cages was used as an indirect measure of colonic motility, as previously described (Barone et al, 1990; Monnikes et al, 1993).

\section{Measurement of Serum Corticosterone}

Blood was collected after decapitation, allowed to clot at room temperature for $1 \mathrm{~h}$ and centrifuged at $500 \mathrm{~g}$ for $30 \mathrm{~min}$. Serum was collected and stored at $-20^{\circ} \mathrm{C}$ prior to analysis. Serum levels of corticosterone were determined by the HPLC method (Wong et al, 1994) with some modifications in terms of pretreatment of the serum and internal standards. Briefly, $100 \mu \mathrm{l}$ of standards or samples were transferred to $2 \mathrm{ml}$ Eppendorf centrifuge tubes. A $25 \mu \mathrm{l}$ aliquot of internal standard solution (dexamethasone, $250 \mathrm{ng} / \mathrm{ml}$, final concentration) was added to the serum followed by $500 \mu \mathrm{l}$ of acetonitrile, and briefly mixed on a touch mixer. The mixture was chilled on ice for $20 \mathrm{~min}$ and then centrifuged at $10000 \mathrm{~g}$ for $10 \mathrm{~min}$ to remove precipi- tated proteins. The supernatant was then transferred to a $1 \mathrm{ml}$ reacti-vial and evaporated to dryness under a stream of nitrogen. Then, $100 \mu \mathrm{l}$ of HPLC mobile phase $(35 \%$ acetonitrile/65\% water) was added and the mixture was ultrasonicated for $10 \mathrm{~min}$ and centrifuged at $1900 \mathrm{~g}$. Finally, the supernatant was transferred to an injection vial for analysis. A $25 \mu$ l portion of the sample or standard solution in the injection vial was subjected to HPLC analysis. HPLC conditions were as follows: The mobile phase was acetonitrile-water $(35: 65)$ and degassed by sonication. Inertsil ODS-3 ( $4.6 \times 250 \mathrm{~mm}$ I.D., $3 \mu \mathrm{m}$, GL Science, Tokyo, Japan) was connected as an LC column. The column was maintained at $40^{\circ} \mathrm{C}$ with a flow rate of $0.5 \mathrm{ml} / \mathrm{min}$. Corticosterone was detected at a wavelength of $240 \mathrm{~nm}$. The HPLC system consisted of HITACHI Model L-7100 pumps (Tokyo, Japan), Tosoh Model AS-8020 autoinjector (Tokyo, Japan), SHIMAZU Model SPD-10AV detector (Tokyo, Japan), and HITACHI Model D-7500 integrator (Tokyo, Japan). The guard column, Inertsil ODS-3 $(1.0 \times 4.0 \mathrm{~cm}$ I.D., $3 \mathrm{~mm})$ was placed between the autoinjector and the separative column, Inertsil ODS-3 $(250 \times 4.6 \mathrm{~mm}$ I.D., $3 \mathrm{~mm})$.

\section{Statistics}

The data were expressed as mean \pm SEM. A $P$-value of less than 0.05 was considered significant. Differences between the values were tested using a two-tailed Student's $t$-test.

\section{RESULTS}

SPF NC/Nga mice were divided into two groups: one group of mice was kept under SPF conditions without WAS (SPF control mice), and another group was kept under SPF conditions and exposed to WAS daily for 4 weeks (SPF WAS mice) (see Materials and methods for details). SPF WAS mice began to scratch within 5 min after starting WAS. This scratching behavior was always observed from the first to the last experiment. The skin gradually became dry and scaly, and finally revealed excoriations, hemorrhages, and hair loss (Figure 2a). Table 1 shows the clinical severity of the AD-like skin lesions in SPF WAS mice. Total severity score increased with age and reached over 11 out of 15 points at the age of 12 weeks (Table 1). On the other hand, SPF control mice did not develop any skin lesions even after 20 weeks (Figure 2b). Age-matched BALB/c mice, which were kept in the same SPF room as NC/Nga mice, showed no significant skin changes with or without WAS.

\section{Histochemistry}

Histologically, the skin lesions of the SPF WAS mice showed moderate hyperkeratosis, epidermal spongiosis, acanthosis and elongation of the rete ridges, and perivascular mononuclear cell infiltration in the dermis (Figure 3a). On the other hand, the skin of the control mice showed no significant changes (Figure $3 \mathrm{~b}$ ). In toluidine blue stain, an increased number of mast cells infiltrated the upper dermis of the skin lesions of the WAS mice (Figure 3c), but not those of the control mice (Figure 3d). Thus, WAS-induced eczematous skin lesions were histologically similar to those of human $\mathrm{AD}$. 

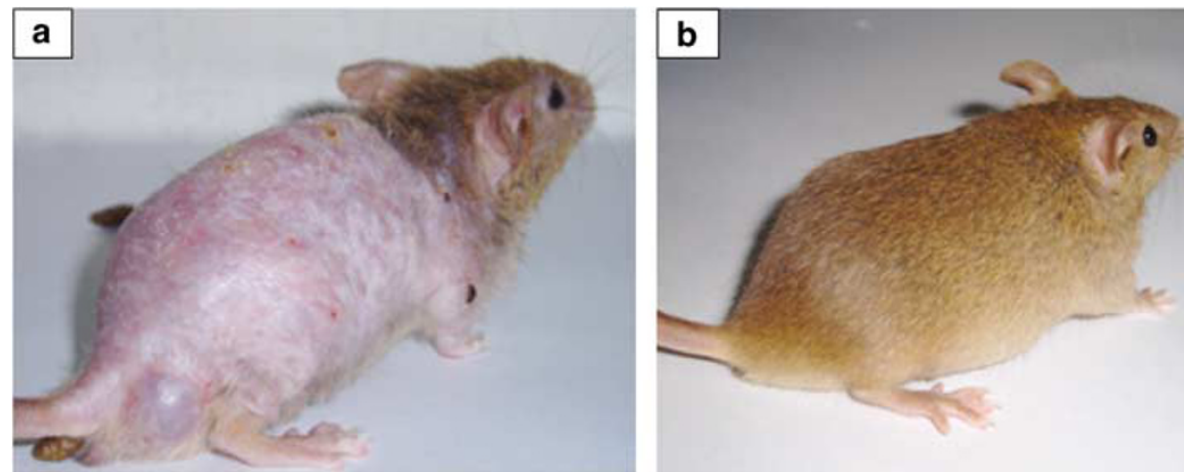

Figure 2 AD-like skin lesions of SPF WAS mice. (a) SPF WAS mice developed eczematous lesions on the neck and back coinciding with the scratched areas. (b) Control mice did not develop any eczematous lesions even after 20 weeks.

Table I The Clinical Severity of the AD-Like Skin Lesions of WAS and Control Mice under SPF Conditions $(n=6)$

\begin{tabular}{lccccc}
\hline Iweeks & $\mathbf{8}$ & $\mathbf{9}$ & $\mathbf{1 0}$ & $\mathbf{1 1}$ & $\mathbf{1 2}$ \\
\hline SPF WAS mice & 0 & $0.3 \pm 0.5$ & $4.7 \pm 1.4 *$ & $7.7 \pm 1.4 *$ & 0 \\
SPF control mice & 0 & 0 & 0 & 0 & 0 \\
\hline
\end{tabular}

The clinical severity score of the dermatitis was evaluated by the previously described criteria for human AD (Leung et al, 1990).

SPF WAS mice: mice were kept under SPF conditions with exposure to WAS

SPF control mice: mice were kept under SPF conditions without WAS.

The values are mean \pm SEM. Zero means no detection of skin lesions.

$* P<0.0$ I vs control.

\section{Measurement of Total IgE}

Many AD patients show elevated levels of serum IgE. NC/Nga mice developing $\mathrm{AD}$-like skin lesions when kept under conventional conditions (conventional mice) are reported to have elevated levels of serum IgE. We measured serum IgE levels in SPF WAS mice at the end of the fourth week (at 1214 weeks of age). Neither SPF control NC/Nga mice nor $\mathrm{BALB} / \mathrm{c}$ mice kept under SPF conditions with or without WAS had elevated levels of serum IgE (data not shown). In contrast, serum IgE levels of SPF WAS mice and conventional mice were comparably elevated and were fourfold higher than SPF control mice (Figure 4). The increment of serum IgE levels in SPF WAS mice was still present after the 8 weeks.

To confirm that WAS could cause appropriate levels of stress in mice, we measured two parameters: the number of fecal pellets and serum corticosterone levels.

\section{Defecation During WAS}

The number of fecal pellets reflects the degree of stress (Barone et al, 1990). Figure 5 shows the number of fecal pellets per hour in SPF WAS mice and SPF control mice. The number of fecal pellets from SPF WAS mice $(10.5 \pm 3.5)$ was five times greater than that of SPF control mice $(2.1 \pm 0.2)(P<0.01)$.

\section{Measurement of Serum Corticosterone}

We measured the serum corticosterone levels in SPF WAS and SPF control mice. The HPLC standard was linear over a range of $10-1000 \mathrm{ng} / \mathrm{ml}$ for carbon-treated serum. The values of serum corticosterone of SPF control and SPF WAS mice were $160 \pm 30$ and $300 \pm 50 \mathrm{ng} / \mathrm{ml}$, respectively (Figure 6). This result indicates that SPF WAS mice felt stress since their levels of serum corticosterone were significantly higher than those of the SPF control mice $(P<0.01)$.

It has been established that CRF increases the secretion of corticosterone. The mean value of serum corticosterone of mice intraperitoneally injected with $50 \mu \mathrm{g} / \mathrm{kg}$ CRF was $320 \pm 50 \mathrm{ng} / \mathrm{ml}$, which was comparable with that of the SPF WAS mice. The increment of corticosterone levels was completely blocked by the CRF receptor antagonist, astressin (Figure 6).

\section{The Effect of CRF on the Elicitation of AD-Like Skin Lesions}

It has been recognized that CRF mimics stress-induced colonic epithelial pathophysiological changes in rats (Santos et al, 1999; Tache et al, 1999). To examine whether or not CRF itself can induce AD-like skin lesions in SPF NC/Nga mice, we injected $50 \mu \mathrm{g} / \mathrm{kg}$ of CRF intraperitoneally in SPF NC/Nga mice under SPF conditions without WAS daily for 4 weeks. Neither a daily injection of CRF nor of saline elicited skin lesions in the mice. Unexpectedly, pretreatment of SPF WAS mice with CRF decreased scratching behavior in a dose-dependent manner, while pretreatment of mice with saline did not affect scratching behavior (Figure 7). To characterize the inhibitory mechanisms of CRF, astressin (a CRF antagonist) was injected intraperitoneally $30 \mathrm{~min}$ before WAS. The six of six mice treated with astressin jumped off the platform. We had already confirmed that the astressin-treated mice have a tendency to jump off the platform during WAS in a dose-dependent manner (data not shown). Thus, it was impossible to examine the effects of the CRF antagonist in WAS.

\section{The Effect of Anti-Substance P (SP) on the Onset of AD}

It has also been also established that SP is one of the most potent pruritogenic neuropeptides. SP can induce itching, 

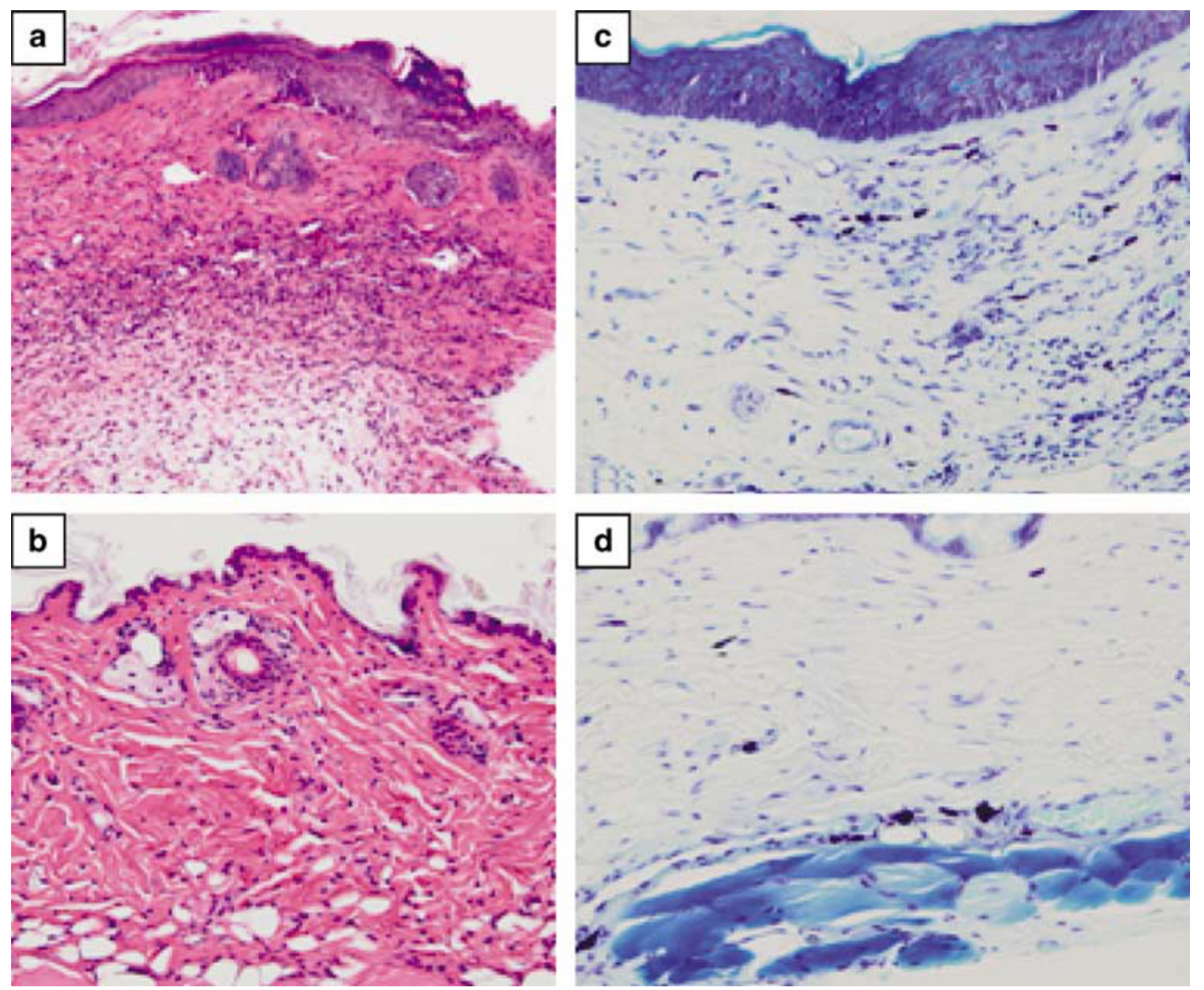

Figure 3 Histological analysis of the skin from SPF WAS and SPF control mice. The sections were stained with HE (a, b) or toluidine blue (c, d). Moderate hyperkeratosis, spongiosis, acanthosis and elongation of the rete ridges in the epidermis and perivascular mononuclear cell infiltrate in the dermis of the SPF WAS mice (a). There are no significant changes to the skin of the SPF control mice (b). Toluidine blue staining showed infiltration of mast cells in the upper dermis of the SPF WAS mice (c) compared to the skin of the SPF control mice (d).

and spantide (a substance $\mathrm{P}$ antagonist) inhibits scratching behavior (Andoh et al, 2001; Ohmura et al, 2004). To examine whether or not spantide inhibits stress-induced AD-like skin lesions in NC/Nga mice, we injected $50 \mathrm{nM}$ of spantide intraperitoneally $30 \mathrm{~min}$ prior to WAS. Spantide, however, did not inhibit stress-induced scratching behavior.

\section{Serum Levels of IL-4, IL-5, and IFN- $\gamma$}

In the acute phase of human $\mathrm{AD}$, the balance of T-cellderived cytokines is skewed to the Th2 type. We measured serum levels of IL-4, IL-5, and IFN- $\gamma$ in conventional mice and SPF WAS mice 4 weeks after initiating the WAS protocol. The serum levels of IL-4, IL-5, or IFN- $\gamma$ of both groups of mice were under the detection limit.

\section{Production of IL-4, IL-5, and IFN- $\gamma$ from Lymph Node Cells}

Since IL-4, IL-5, and IFN- $\gamma$ could not be detected in the sera of conventional and SPF WAS mice, we analyzed cytokine production of cultured lymph node (LN) cells of these mice. Stimulation with Con A caused LN cells to produce these cytokines (Table 2). A small amount of IL-4 was detected in both conventional and SPF WAS mice, $35 \pm 6$ and $28 \pm 4 \mathrm{pg} /$ $\mathrm{ml}$, respectively. In contrast, IL-5 was detected comparably in both conventional and SPF WAS mice, $180 \pm 24$ and $120 \pm 23 \mathrm{pg} / \mathrm{ml}$, respectively. The amounts of IFN $-\gamma$ in conventional and SPF WAS mice were $500 \pm 32$ and $600 \pm 23 \mathrm{pg} / \mathrm{ml}$, respectively, which were comparable to those of SPF control mice $(450 \pm 45 \mathrm{pg} / \mathrm{ml})$.

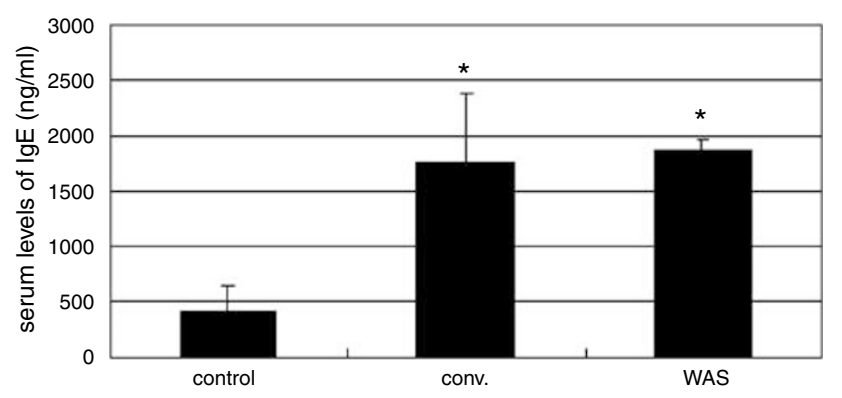

Figure 4 Serum levels of IgE. Serum levels of $\lg E$ in the NC/Nga mice kept under SPF conditions (control), the NC/Nga mice developing AD-like skin lesions (conv.), and the SPF WAS mice. The bars represent mean \pm SEM, $n=4-6 /$ group; $* P<0.0$ I vs control.

\section{DISCUSSION}

$\mathrm{AD}$ is a pruritic and chronic inflammatory skin disease associated with a genetic background of atopic diathesis. The cutaneous changes are caused directly by repeated rubbing and scratching to relieve itching. $\mathrm{AD}$ develops as a consequence of a complex interaction of genetic, environmental, and immunological factors, especially bacterial infection. A thousand studies on AD have been carried out mainly in the light of immunological aspects and skin barrier function. It is still unclear whether or not psychological stress by itself can trigger the development of AD.

Psychological stress is undoubtedly an important diseasemodifying factor in $\mathrm{AD}$ patients and/or people genetically 


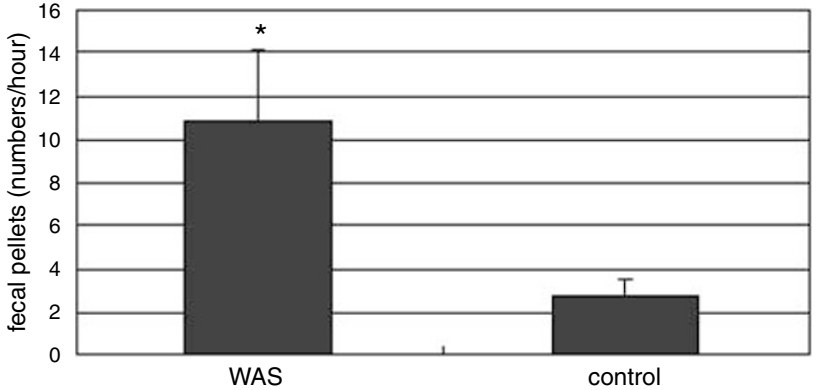

Figure 5 Effect of WAS on fecal pellet output. The bars represent mean \pm SEM, $n=5-9 /$ group; $* P<0.0$ I vs control.

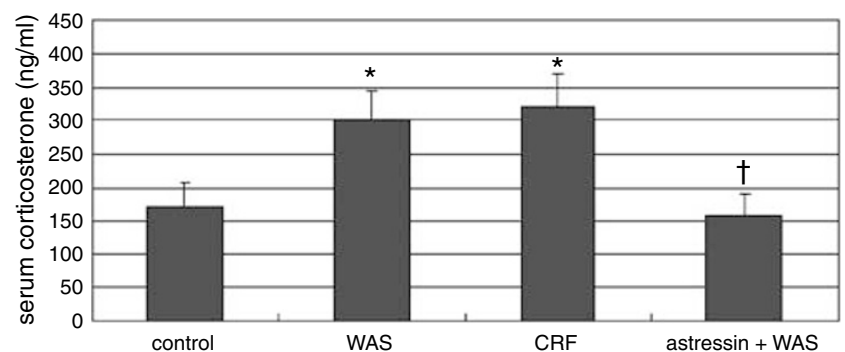

Figure 6 Effect of WAS, CRF, or astressin on serum corticosterone levels. The values are mean \pm SEM, $n=4-5$ /group; ${ }^{*} P<0.0$ I vs control, ${ }^{\dagger} P<0.01$ vs WAS.



Figure 7 Effect of CRF on scratching behavior. Control: saline was injected intraperitoneally $30 \mathrm{~min}$ prior to performing the WAS protocol. The values are mean \pm SEM, $n=4-5 /$ group; $* P<0.01$ vs control.

predisposed to $\mathrm{AD}$ (Wright et al, 2004). $\mathrm{AD}$ often exacerbates when the patients feel frustrated or experience other stressful events such as examinations, hard work, or human relationships. Once AD patients feel severe itching, they cannot refrain from scratching. Consequently, a vicious cycle is formed: pruritus, scratching and worsening of dermatitis. Schmid-Ott et al (2001a,b) showed that psychological stress increased CD8 + /CD11b + T lymphocytes, natural killer cells, and eosinophils in $\mathrm{AD}$ patients when compared with healthy controls. In addition, Garg et al (2001) reported that psychological stress perturbed epidermal permeability, indicating that stress affects the skin barrier function.

Interestingly, there is a growing evidence that both stress and anxiety are associated with the release of neuropeptides as secretagogues of various effector cells which, in turn, secrete pruritogenic and proinflammatory mediators (Giannetti and Girolomoni, 1989). In the field of gastrointestinal research, stress induces irritable bowel syndrome,
Table 2 Production of IL-4, IL-5, and IFN- $\gamma$ from Lymph Node Cells $(n=6)$

\begin{tabular}{lccc}
\hline & IL-4 (pg/ml) & IL-5 (pg/ml) & IFN- $\boldsymbol{\gamma}$ (pg/ml) \\
\hline SPF control mice & ND & ND & $450 \pm 45$ \\
Conventional mice & $35 \pm 6$ & $180 \pm 24$ & $500 \pm 32$ \\
SPF WAS mice & $28 \pm 4$ & $120 \pm 23$ & $600 \pm 23$ \\
\hline
\end{tabular}

ND: not detected. The values are mean \pm SEM.

SPF control mice: mice were kept under SPF conditions without WAS.

Conventional mice: mice were kept under conventional conditions without WAS.

SPF WAS mice: mice were kept under SPF conditions with exposure to WAS.

gastric ulcers, or gastric hemorrhages (Bennett et al, 1998). It has been established that physical and psychological stressors can induce marked alterations in water and electrolyte transport across the epithelium in the small intestines of rats (Santos et al, 2001; Bonaz and Tache, 1994). In those experiments, WAS, as psychological stress, altered the barrier and transport properties of the small intestine. Bonaz and Tache (1994) observed that WAS increased pellet output and induced the emergence of fos-positive cells in the hypothalamus, locus coeruleus, and lateral septum. In addition, a CRF receptor antagonist, astressin, decreased WAS-stimulated fecal output and reduced WAS-induced c-fos expression. Those rodents did not jump off the platform. The difference in the behavior observed might be due to innate differences between $\mathrm{NC} / \mathrm{Nga}$ mice and rats. These findings indicate that WAS can stimulate neurons and colonic motor function through the CRF pathways. In addition, CRF can generate stress-induced phenomena, such as increased colonic ion secretion and permeability to ions and horseradish peroxidase, which were inhibited by a CRF receptor antagonist (Santos et al, 1999).

The NC/Nga mouse has been extensively studied as a model of human AD. AD-like skin lesions develop when kept under conventional conditions, but not under SPF conditions. By using a WAS technique, we could induce ADlike eczematous skin lesions in NC/Nga mice even under SPF conditions (Figure 2). The skin lesions showed hyperkeratosis, epidermal spongiosis, acanthosis, and lymphocyte infiltration (Figure 3). Serum IgE levels were also elevated (Figure 4). These findings meet the essential features of $\mathrm{NC} / \mathrm{Nga}$ mice developing $\mathrm{AD}$-like dermatitis under conventional conditions and human $\mathrm{AD}$ patients.

In our experiment, $\mathrm{NC} / \mathrm{Nga}$ mice continued scratching during WAS, but BALB/c mice did not scratch at all. This result strongly indicates that not only stress but also a genetic factor is also responsible for scratching.

How does stress induce itching or scratching? Stressinduced scratching behavior is mediated by both a central neural pathway and a peripheral neural pathway such as sensory neurons. A central neural pathway for itching may be related to CRF and/or opioid peptides, while a peripheral neural pathway for itching is related to histamine, serotonin, tumor necrosis factor- $\alpha$, leukotrienes, neuropeptides, and mast cells.

With regard to the peripheral pathway, psychological stress stimulates sensory neurons as well as the hypothalamus in both human and mice. Sensory neurons secrete several kinds of neuropeptides, such as CRF, nerve growth 
factor, neurotensin, calcitonin gene-related peptide, and SP. These peptides, especially SP, can induce itching; an antagonist to SP inhibits scratching behavior. In our experiments, however, an SP antagonist, spantide, did not inhibit the stress-induced scratching behavior of WAS mice. Therefore, the results strongly suggest that there are different mechanisms between psychological stress-induced and neuropeptide-induced scratching behavior. Namely, psychological stress-induced scratching behavior should be mediated by central pathway. There is no doubt that CRF and/or CRF receptor may be involved in the scratching behavior of WAS mice. Stress causes the release of CRF from the hypothalamus and, in turn, CRF stimulates the pituitary gland to release adrenocorticotropic hormone (ACTH), which induces corticosterone secretion from the adrenal gland. This sequential pathway is known as the HPA axis. Children with $\mathrm{AD}$ were reported to exhibit blunted cortisol response compared to healthy children (BuskeKirschbaum et al, 1997). Sternberg et al (1989a,b) demonstrated that the Lewis rat, which has genetically blunted HPA axis reactivity in response to CRF, was highly vulnerable to proinflammatory stimuli compared to the histocompatible Fischer rat. On exposure to various stressors, the Lewis rat significantly attenuated ACTH and corticosterone secretion as well as reduced CRF mRNA levels in the paraventricular nucleus of the hypothalamus compared to the Fischer rat. In our experiments, WAS increased serum corticosterone levels to levels similar to those seen with an intraperitoneal CRF injection (Figure 6). This result indicates that the HPA axis was functional in our mouse model. It is of great interest that CRF inhibited scratching behavior of SPF WAS mice in a dose-dependent manner, while pretreatment of mice with saline did not affect scratching behaviour (Figure 7). This is the first report that $\mathrm{CRF}$ inhibits scratching behavior in atopic dermatitis model mice, NC/Nga. The inhibitory effect of CRF might not be related to corticosterone because both stress and an intraperitoneal CRF injection increased serum corticosterone to the same extent (Figure 6). These data raised the possibility that the inhibitory effect of CRF on scratching behavior might be regulated by neuronal, immunocompetent, or other cells in which the cellular functions are modified through CRF receptor signaling. $\mathrm{CRF}$ influences the function of the immune system indirectly through activation of the stress response and directly through local modulatory actions on inflammatory responses (Webster et al, 1998). Stress selectively amplifies Th2 immune responses. In another words, catecholamines stimulate IL-10 production and inhibit IFN- $\gamma$, IL-2, and IL12 production. On the other hand, glucocorticoids inhibit IL-12, IFN- $\gamma$, and IL-2 production. However, we could not detect IL-4, IL-5, and IFN- $\gamma$ in the sera of the WAS mice. Bienenstock pointed out that psychological stimulation alone caused mucosal mast cell degranulation and mediator release in rats (Bienenstock et al, 1991; MacQueen et al, 1989). This evidence is an extension of the idea that mast cells and nerves communicate with each other. Theoharides et al $(1995,1998)$ demonstrated that intradermal administration of CRF activated mast cells in rat skin, and that acute immobilization stress could trigger mast cell degranulation in rat skin (Singh et al, 1999). They, however, did not confirm whether or not stress induced dermatitis. As described by Theoharides, we confirmed that in NC/Nga mice, intradermal administration of CRF induced mast cell degranulation in the skin. Namely, CRF has proinflammatory effects in the skin. However, intraperitoneal administration of CRF did not induce mast cell degranulation in the skin (data not shown). Also, anti-substance $\mathrm{P}$ did not inhibit stress-induced scratching behavior. These results suggest that the central pathway may be more important than the peripheral neural pathway in psychological stressinduced scratching behavior. It is still unclear whether CRF can cross the blood-brain barrier. Since CRF is one of the hormones produced in the hypothalamus, it may cross the blood-brain barrier. Although we have not identified the pathway that mediates itching precisely, psychological stress-induced scratching behavior should be mediated by the central neural pathway and CRF may have an antiinflammatory effect on the development of stress-induced $A D$ via the central pathway (Biro et al, 2005; Steinhoff et al, 2006). In conclusion, we demonstrate for the first time that in NC/Nga mice psychological stress alone can trigger the $\mathrm{AD}$-like skin lesions and pretreatment with $\mathrm{CRF}$ inhibits scratching behavior. The analyses of cellular response to CRF may be of great importance. The understanding of stress-induced crosstalk through hormones, neurotransmitters, and cytokines will open a new era of $\mathrm{AD}$ research.

\section{ACKNOWLEDGEMENTS}

This work was supported in part by a research grant from the Ministry of Education, Science, Sports and Culture of Japan. We are grateful to Professor John Bienenstock (McMaster University, ON, Canada) for the pre-review of the manuscript.

\section{DISCLOSURE/CONFLICT OF INTEREST}

None declared.

\section{REFERENCES}

Akiyama H, Amano H, Bienenstock J (2005). Rat tracheal epithelial responses to water avoidance stress. J Allergy Clin Immunol 116: 318-324.

Andoh T, Katsube N, Maruyama M, Kuraishi Y (2001). Involvement of leukotriene $\mathrm{B}(4)$ in substance $\mathrm{P}$-induced itch-associated response in mice. J Invest Dermatol 117: 1621-1626.

Barone FC, Deegan JF, Price WJ, Fowler PJ, Fondacaro JD, Ormsbee III HS (1990). Cold-restraint stress increases rat fecal pellet output and colonic transit. Am J Physiol 258: G329-G337.

Bennett EJ, Tennant CC, Piesse C, Badcock CA, Kellow JE (1998). Level of chronic life stress predicts clinical outcome in irritable bowel syndrome. Gut 43: 256-261.

Bienenstock J, MacQueen G, Sestini P, Marshall JS, Stead RH, Perdue MH (1991). Mast cell/nerve interactions in vitro and in vivo. Am Rev Resp Dis 143: S55-S58.

Biro T, Ko MC, Bromm B, Wei ET, Bigliardi P, Siebenhaar F et al (2005). How best to fight that nasty itch - from new insights into the neuroimmunological, neuroendocrine, and neurophysiological bases of pruritus to novel therapeutic approaches. Exp Dermatol 14: 225-240.

Bonaz B, Tache Y (1994). Water-avoidance stress-induced c-fos expression in the rat brain and stimulation of fecal output: role of corticotropin-releasing factor. Brain Res 641: 21-28. 
Buske-Kirschbaum A, Jobst S, Psych D, Wustmans A, Kirschbaum C, Rauh W et al (1997). Attenuated free cortisol response to psychosocial stress in children with atopic dermatitis. Psychosom Med 59: 419-426.

Castagliuolo I, Lamont JT, Qiu B, Fleming SM, Bhaskar KR, Nikulasson ST et al (1996). Acute stress causes mucin release from rat colon: role of corticotropin releasing factor and mast cells. Am J Physiol 271: G884-G892.

Garg A, Chren MM, Sands LP, Matsui MS, Marenus KD, Feingold KR et al (2001). Psychological stress perturbs epidermal permeability barrier homeostasis: implications for the pathogenesis of stress-associated skin disorders. Arch Dermatol 137: 53-59.

Giannetti A, Girolomoni G (1989). Skin reactivity to neuropeptides in atopic dermatitis. Br J Dermatol 121: 681-688.

Hanifin JM (1982). Atopic dermatitis. J Am Acad Dermatol 6: 1-13.

Kuster W, Petersen M, Christophers E, Goos M, Sterry W (1990). A family study of atopic dermatitis. Clinical and genetic characteristics of 188 patients and 2151 family members. Arch Dermatol Res 282: 98-102.

Leung DY, Bieber T (2003). Atopic dermatitis. Lancet 361: 151-160.

Leung DY, Hirsch RL, Schneider L, Moody C, Takaoka R, Li SH et al (1990). Thymopentin therapy reduces the clinical severity of atopic dermatitis. J Allergy Clin Immunol 85: 927-933.

Levenstein S, Prantera C, Varvo V, Scribano ML, Andreoli A, Luzi $\mathrm{C}$ et al (2000). Stress and exacerbation in ulcerative colitis: a prospective study of patients enrolled in remission. $\mathrm{Am}$ J Gastroenterol 95: 1213-1220.

MacQueen G, Marshall J, Perdue M, Siegel S, Bienenstock J (1989). Pavlovian conditioning of rat mucosal mast cells to secrete rat mast cell protease II. Science 243: 83-85.

Matsuda H, Watanabe N, Geba GP, Sperl J, Tsudzuki M, Hiroi J et al (1997). Development of atopic dermatitis-like skin lesion with IgE hyperproduction in NC/Nga mice. Int Immunol 9: 461-466.

Matsumoto M, Ra C, Kawamoto K, Sato H, Itakura A, Sawada J et al (1999). IgE hyperproduction through enhanced tyrosine phosphorylation of Janus kinase 3 in NC/Nga mice, a model for human atopic dermatitis. J Immunol 162: 1056-1063.

Million M, Tache Y, Anton P (1999). Susceptibility of Lewis and Fischer rats to stress-induced worsening of TNB-colitis: protective role of brain CRF. Am J Physiol 276: G1027-G1036.

Monnikes H, Schmidt BG, Tache Y (1993). Psychological stress-induced accelerated colonic transit in rats involves hypothalamic corticotropin-releasing factor. Gastroenterology 104: 716-723.

Ohmura T, Hayashi T, Satoh Y, Konomi A, Jung B, Satoh H (2004). Involvement of substance $\mathrm{P}$ in scratching behaviour in an atopic dermatitis model. Eur J Pharmacol 491: 191-194.

Rudikoff D, Lebwohl M (1998). Atopic dermatitis. Lancet 351: $1715-1721$.

Santos J, Benjamin M, Yang PC, Prior T, Perdue MH (2000). Chronic stress impairs rat growth and jejunal epithelial barrier function: role of mast cells. Am J Physiol Gastrointest Liver Physiol 278: G847-G854.

Santos J, Saunders PR, Hanssen NP, Yang PC, Yates D, Groot JA et al (1999). Corticotropin-releasing hormone mimics stressinduced colonic epithelial pathophysiology in the rat. $\mathrm{Am}$ J Physiol 277: G391-G399.

Santos J, Yang PC, Söderholm JD, Benjamin M, Perdue MH (2001). Role of mast cells in chronic stress induced colonic epithelial barrier dysfunction in the rat. Gut 48: 630-636.

Schmid-Ott G, Jaeger B, Adamek C, Koch H, Lamprecht F, Kapp A et al (2001a). Levels of circulating CD8(+) $\mathrm{T}$ lymphocytes, natural killer cells, and eosinophils increase upon acute psychosocial stress in patients with atopic dermatitis. J Allergy Clin Immunol 107: 171-177.
Schmid-Ott G, Jaeger B, Meyer S, Stephan E, Kapp A, Werfel T (2001b). Different expression of cytokine and membrane molecules by circulating lymphocytes on acute mental stress in patients with atopic dermatitis in comparison with healthy controls. J Allergy Clin Immunol 108: 455-462.

Selye $H$ (1946). The general adaptation syndrome and the disease of adaptation. J Clin Endocrinol 6: 117-230.

Singh LK, Pang X, Alexacos N, Letourneau R, Theoharides TC (1999). Acute immobilization stress triggers skin mast cell degranulation via corticotropin releasing hormone, neurotensin, and substance P: a link to neurogenic skin disorders. Brain Behav Immun 13: 225-239.

Steinhoff M, Bienenstock J, Schmelz M, Maurer M, Wei E, Biro T (2006). Neurophysiological, neuroimmunological, and neuroendocrine basis of pruritus. J Invest Dermatol 126: $1705-1718$.

Sternberg EM, Hill JM, Chrousos GP, Kamilaris T, Listwak SJ, Gold $\mathrm{PW}$ et al (1989a). Inflammatory mediator-induced hypothalamic-pituitary-adrenal axis activation is defective in streptococcal cell wall arthritis-susceptible Lewis rats. Proc Natl Acad Sci USA 86: 2374-2378.

Sternberg EM, Young III WS, Bernardini R, Calogero AE, Chrousos GP, Gold PW et al (1989b). A central nervous system defect in biosynthesis of corticotropin-releasing hormone is associated with susceptibility to streptococcal cell wall-induced arthritis in Lewis rats. Proc Natl Acad Sci USA 86: 4771-4775.

Suto H, Matsuda H, Mitsuishi K, Hira K, Uchida T, Unno T et al (1999). NC/Nga mice: a mouse model for atopic dermatitis. Int Arch Allergy Immunol 120(Suppl 1): 70-75.

Tache Y, Martinez V, Million M, Rivier J (1999). Corticotropinreleasing factor and the brain-gut motor response to stress. Can J Gastroenterol 13(Suppl): 18A-25A.

Theoharides TC, Singh LK, Boucher W, Pang X, Letourneau R, Webster $\mathrm{E}$ et al (1998). Corticotropin-releasing hormone induces skin mast cell degranulation and increased vascular permeability, a possible explanation for its proinflammatory effects. Endocrinology 139: 403-413.

Theoharides TC, Spanos C, Pang X, Alferes L, Ligris K, Letourneau $\mathrm{R}$ et al (1995). Stress-induced intracranial mast cell degranulation: a corticotropin-releasing hormone-mediated effect. Endocrinology 136: 5745-5750.

Uehara M, Kimura C (1993). Descendant family history of atopic dermatitis. Acta Derm Venereol 73: 62-63.

van de Langerijt AG, van Lent PL, Hermus AR, Sweep CG, Cools AR, van den Berg WB (1994). Susceptibility to adjuvant arthritis: relative importance of adrenal activity and bacterial flora. Clin Exp Immunol 97: 33-38.

Wamboldt MZ, Laudenslager M, Wamboldt FS, Kelsay K, Hewitt J (2003). Adolescents with atopic disorders have an attenuated cortisol response to laboratory stress. J Allergy Clin Immunol 111: $509-514$

Webster EL, Torpy DJ, Elenkov IJ, Chrousos GP (1998). Corticotropin-releasing hormone and inflammation. Ann NY Acad Sci 840: 21-32.

Wong YN, Chien BM, D'mello AP (1994). Analysis of corticosterone in rat plasma by high-performance liquid chromatography. J Chromatogr B Biomed Appl 661: 211-218.

Wright RJ, Finn P, Contreras JP, Cohen S, Wright RO, Staudenmayer J et al (2004). Chronic caregiver stress and IgE expression, allergen-induced proliferation, and cytokine profiles in a birth cohort predisposed to atopy. J Allergy Clin Immunol 113: 1051-1057.

Yagi R, Nagai H, Iigo Y, Akimoto T, Arai T, Kubo M (2002). Development of atopic dermatitis-like skin lesions in STAT6deficient NC/Nga mice. J Immunol 168: 2020-2027. 